\title{
釜石地方森林組合における東日本大震災からの復興過程
}

\section{Post-Disaster Reconstruction Process at the Kamaishi Forestry Cooperative}

\author{
阿部瀬良*山本信次 ${ }^{* *}$ \\ Sera $\mathrm{ABE}^{*}$ Shinji YAMAMOTO** \\ (岩手大学大学院農学研究科*岩手大学農学部**) \\ (Graduate School of Agriculture, Iwate University* Faculty of Agriculture, Iwate University**)
}

\section{I はじめに}

\section{1. 背景・目的}

2011 年 3 月 11 日に東北地方を襲った東日本大震災に 伴う人的被害は死者・行方不明者合わせて約 192,000 人に上っだ11。震災は日本林業にも多大な影響を及ぼ した。本稿では地域の森林管理を担う主体として岩手県 釜石地方森林組合（以下釜石森組）について取り上げ， それが被災から復興していく過程に焦点を当てている。 釜石森組は施業集約化優良事業体と認定され，県内だけ でなく国内での評価も高かったが,被害は甚大であった。 しかし今では再建を軌道に乗せている。

復興と関わり,ここで「レジリアンス resilience」と いう概念について触れたい。これは元々生態学の分野で 用いられていた概念で，外界からの変化・変動に対して システムが衝撃を吸収するなどの反応をしながら，自身 の機能や構造を維持する能力を示す。日本での研究事例 はまだ少ないものの，社会科学を含む様々な分野にレジ リアンスの議論が広がり初めている注2)。今回の災害に 関して「組織が大きなショックに際してどれだけ柔軟に, どれだけ迅速に体制を構築できたか」りを考えたい。

東日本大震災後, 地域コミュニティーの対応やその改 善点からレジリアンスに関わる議論を促す研究が行われ

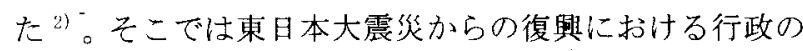
対応が必ずしも適切ではなかったと指摘されている。そ こで今後の災害対策では, 公的機関による支援に頼らず， 住民自らが組織の機能を再構筑していく体制を整えるこ とが重要であり，その為には民間団体同士，或いは民間 と行政閒でのネットワーク形成が大きな役割を果たすと されている ${ }^{3)}$ 。東日本大震災からの復興過程，及び地域 の林業主体の復興に関する研究は少ないため，上記提言 を踏まえて今後の災害対応について考えたい。

\section{2. 調查手法}

文献調査及び，釜石森組・岩手県森林組合連合会（以 下県森連）・岩手県・釜石市・株式会社新日鐵住金棒線
事業部釜石製鐵所（以下新日鐵釜石）への聞き取り調査 を行った。それぞれの主体に震災前後で釜石森組との連 携について，また県・市からは復興計画と進捗状況，今 後の課題について聞き取りを行った。まず釜石森組の概 要と震災以前の様子から「釜石森組がどのような点で優 れていたのか」を明らかにした。同様に釜石森組の被害 と東北の木材加工工場の被害を調へ，「優れていた点」 が「どのような被害を受けたのか」を把握した。以上を 踏まえ，釜石森組の復與を促進，或いは阻害した要因に ついて既往研究の提言の検証を行いながら考察しレジ リアンス獲得の為に地域の森林管理を担う主体が取るべ き備えや発生時の対応について提言を試みる。

\section{III震災以前の事業展開}

\section{1. 釜石地方森林組合の概況とこれまでの事業展開}

1985 年合併により広域組合となった釜石森組は釜石 市と大椭町の森林を管轄している。事業収入は凡そ 3 億 円（2009 年），内 2 億円余りが森林整備によるものであ る。作業班は，造・育林を主とする請負班が約 40 人 13 班, 集約化施業の担い手である直営班が 10 人 2 班となっ ている。事業の主体は間伐だが利用間伐を中心とする林 産事業に明確に重点を置くようになったのは 2000 年代 になってからで，それまでは長期に亘り基礎自治体の公 共森林整備事業に依存寸る構造であった。しかし公共事 業の受注量減少と共に事業確保に䀣念が生じ始めるな ど，事業が停滞し始めた。そこで本来の役割である「組 合員の森林整備促進」を組織的に行う為，「健康な森ら くり推進隊」が設立されたり。釜石森組ではコンピュー ターでデータを一元管理することで効率的に施業集約化 を推進していた。コンピューターに中長期的な見通しを 持つ為の普遍的経営ノウハウを，一部の普遍化できない ノウハウは職員の経験として蓄積していた。その結果 2007 年に集約化施業モデル組合に指定され，更に間伐施 業集約化一力を入れて取組むようになった ${ }^{5) 。}$ 
釜石森組では「地域に根差した林業団体」という意識 の下，管轄森林の属する流域環境の保全・改善へ貢献し ようとする取り組みも行っている。2009年から釜石森組 は新日本製鐵釜石製鐵所・株式会社三陸バイオマス・釜 石市と協働で「緑のシステム創造事業」に取り組み，そ の一環として木質バイオマス利用の混焼発電に協力して いる。本事業については後述する。また釜石森組は J-VER によるCO2 排出権販売の収益を地域の造林費に充てる取 り組みも行っている。森林の環境価值高め, クレジッ トによって収益を出すことで，森林管理に対する所有者 の関心，理解も高まり，団地化が促進された。

県内での釜石森組の位置付けについてみると「活力の ある事業体と言え壮釜石」（県担当者）という見方があ るようにその評価は極めて高い。元々釜石地方は土地生 産性が低く, 組合としては零細で一時は経営が傾きかけ ていたが，乙れを立て直し国から優良事業体と認定され たことが大きく評価されている。集約化施業やバイオマ スの活用など国に先駆けて取り組んだこと，素材生産だ けでなく間伐コスト低下に向けた取り組みも進んでいる ことなどが理由であり，組織に携わる人の力が示唆され ている。釜石市からも釜石森組は実力のある林業団体と 認められており，「何かあれば相談する」（市担当者） と信頼が奇せられていることが同える。この釜石市との 連携体制が復與過程でも役立っており後述する。

\section{3. 集約化の取り組み}

施業集約化は各所有者の持つ小規模な林地をまとめ, 效率的な生産を行うことを目的とした取り組みであり， 釜石森組では特に活発である。2004 年 4 月，S 組合長（当 時）の呼びかけにより, 整備が必要な森林の掘り起こし をして施業を提案し，地区座談会での説明やプロット調 查と森林診断書の作成に取り組み，集約化施業の中核を 担う「健康な森づくり推進隊」（以下『推進隊』）が発 足した。「推進隊」は 1 つの現場で間伐作業に入る際， 隣接する所有者にも働きかけて面積を䌕める他，各地区 の代表者に働きかけることで集約化を実現している6)。

集約化について合意を形成するには，組合員を含めた 森林所有者からの信頼を獲得することが必要である。そ の為釜石森組では, 説明や境界確認の立会, 要望聴取な どにおいてきめ紐やかな対応が行われている。これにつ いては故 S 組合長（当時）の「お客さんの山の価值を高 めるということにおいて手を抜くな」という言葉が象徴 的である。このような丁寧で誠実な施業により，釜石森 組は組合員との信頼関係を築いていった。

\section{4. 木材生産・販売}

2004 年以前の素材生産量は概小 1 万 $\mathrm{m} 3$ 程度で推移し ていたが, 2010 年には約 2 万 $\mathrm{m} 3$ に伸びた。一時的に落
ち込むことはあったものの，2003 年の $8 ， 144 \mathrm{~m} 3 /$ 年に比 心急増している7)。釜石森組では 2009 年から積極的に 高性能林業機械を導入した。導入に当たっては,「所有 者のメリットになるよう，生産コストを上げないこと」

( $\mathrm{T}$ 参事) を重要視している。この考え方にも，組合員 の利益を第一と捉える釜石森組の理念が表れている。集 約化が進み, 高性能林業機械が導入されたことで, 生産 性は倍增している泎3)。

生産された素材のA・B・C材（本稿では各々良質材・ 中質材・低質材とする）の割合は 1:6:3である。東北 地方では木材生産が B 材のみに依存才る傾向が明らかに なっている ${ }^{8)}$ が，釜石森組はA 材生産にも積極的に取り 組んできた。またこうした割合で生産した素材を余さ ず販売することが, 当地域の素材生産の挔大を成功させ る鍵となる。震災以前, 釜石森組で生産したA 材は地元 製材業者に，B 材は宮古市・大船渡市のセイホクグルー プ合板工場への出荷を中心に県内で取引されていた。C 材は従来の製紙原料の他, 釜石森組では後述の「緑のシ ステム創造事業」を通じ，バイオマス燃料として地元製 鉄所に供給していた。このような販路を築くことで，生 産が拡大した素材をさばききる体制を構築していたので ある。

「緑のシステム創造事業」は，釜石市内の林業・製造 業・行政が連携し，従来林内に放置されていた未利用資 源（木質バイオマス）を収集し，活用することを目的と している泣 4)。事業の始まりは，新日鐵釜石が国による 「みどりの産業再生プロジェクト」（森林整備加速化・ 林業再生事業）を受けて混焼発電に取り組もうと考えた ことであった。そこで 2009 年，岩手県・釜石市・釜石森 組・新日鐵釜石の 4 者で「木質バイオマス高度利用研究 会」が発足し, 市を中心に「緑のシステム創造事業」と して展開した。この 4 主体は現在も週 1 回の打ち合わせ を行うなど連携が維持されている。同年 9 月には未利用 資源からのチップ生産を担う株式会社三陸バイオマスが 設立され，釜石森組からC材供給が始まった。その後, 2010 年 10 月の混焼発電実証試験を経て, 2011 年から本 格稼働となるはずであった。

\section{III 震災による被害状況}

釜石森組では, S 組合会長, F 総務課長など計 5 名が亡 くなった ${ }^{9}$ 。事務所も流失し, 施業集約化の為のデータ やノウハウを記録したコンピューターなども全て失われ た。素材生産にお゙いては，とりわけB 材取引への影響が 大きかった。A 材は元々の取引相手が内陸にあり，被災 していなかったので,そのまま県内での流通が保たれた。 
またC材も，毎年 7 月から出荷を行っている為洁5), 出 荷量に変化は無かった。しかしB材については, 納入先 であった沿岸に律した合板工場が津波被害を受け, 出荷 できなくなった。

釜石に限らず東北全体でみれば東日本大震災によって 被災した木材加工工場は112 か所, 被害額は508 億円に 上る ${ }^{10)}$ 。岩手・宮城沿岸では主力合板工場 6 か所が被災 し, 国内生産能力の約 3 割が失われた ${ }^{11) 。 B ~}$ 内だけでも 25 万 $\mathrm{m} 3$ が出荷できなくなった。製紙工場も 操業を停止した為に, 県内では $\mathrm{B}$ 材同様製紙用原料の C 材についても行き場を失った。

日本製紙は，2011年 4 月に岩沼工場が非，9月に石 巻工場が操業を再開したi゙7)。三菱製紙八戸工場は 5 月

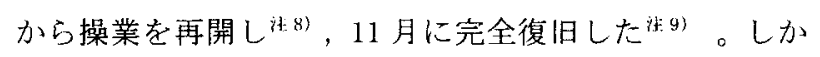
し，未だ岩手県内の C 材は供給過剩状態にある洋10)。セ イホクグループの合板工場も順次復旧してきた。まずセ イホク石巻工場が, 2011 年 8 月下旬から一部生産を再開 しiF１1)，宮古市に工場があるホクョープライウッドも 11 月時点で生産を再開している非12)。しかしその操業 率・原木消費量が震災前まで回復しておらず，県全体で の原木生産量は, 2012 年 5 月時点で一昨年の 6 割に留 まっている(13)。一方北日本プライウッドは11月に事 業再開を断念した䄄( - $)$ 。子会社である大船渡プライウッ

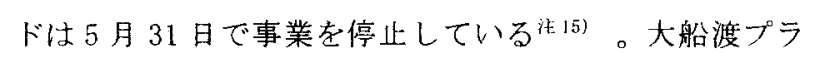
イウッドが再開を断念したことで, 10 万 $\mathrm{m} 3$ の需要が喪 失した上見積もられている。このような状況の為に, 釜 石森組では新たな販路を確保する必要に迫られた。

\section{IV 復興過程}

\section{1. 事業基盤の再編}

震災によって釜石森組は人的被害之資金不足に宿っ た。人的被害に伴い会計や事務手続きなどの事業が停渔 しないよう, 人事異動の発令や臨時職員の採用, 職員 $O G$ にも経理事務支援の要請が行われた。近郊の遠野地方森 林組合からも各種事務手続きの支援が行われた ${ }^{12}$ 。

資金不足を補ったのが市発注の瓦䂺撤去業務への参画 とJ-VERに上る収入である。震災直後に釜石森組が被災 を免れた高性能林業機械を活かし，復與作業を行うこと を釜石市に申し入れたところ，釜石市長からの感謝の意 として釜石市建設業協会一登録された ${ }^{13)}$ 。市は瓦碩撤去 の仕事を協会へ発注して㧍り，二れによって正式な業務 として瓦础撤去が行えるようになった。この措置仕過去 に遡って適用された為，それまでの作業分にも支払いが 行われ ${ }^{14}$ ，被災に上る資金不足補う非常に役立つもの であったと言える。J-VERについては，全国的な被災地
支援気運の高まりにより購入する企業が増加した。当初 は県森連の H 氏が販売㲅口として釜石森組の代理を担 い, 震災後の 1 年間で約 $2,600 t$ 分 $(2,800$ 万円) が売 れ，2012 年 10 月時点には約 3, $700 \mathrm{t}$ まで販売実績が伸 びた。収入は木材の県外輸送費や山林の補修など被災後 に増えた施業コスト補填などに充てられた。

木質バイオマス・石炭混焼発電への影響は, 発電所が 浸水のために一時的に操業を停止した程度に留まってお り，影響は殆どなかった。県内では製紙用チップの流通 停滞により材価が下落しているが注16)，混焼発電に関し ては材価の下落, 搬入停滞とも見られない。当事業には 市から補助が出ているが, バイオマスによる電力の固定 買い取り制度により補助を減額できる可能性がある。し かし新日鐵釜石は, 補助をそのまま打ち切るのではなく, 財源を山側（釜石森組）に還元し，林業の競争力を高め られるようにする方法を考えるべきだと主張している。

\section{2. 施業集約化の立て直しと施業上の課題}

被災直後, 施業集約化を立て直す為に最も重要であっ たのが組合員の消息と経済状況の把握であった。所有者 の被災や避難などで不明となった消息は口コミによって 徐々に回復した。T 参事はこの過程について,「大規模 合併していたら組合員との顔の見える関倸は構築でき ず，ロコミでは無理だった」と振り返っている。

釜石森組では，今後，施業集約化のデータ・ノウハウ を職員同士で共有することが確認された。デー夕は遠隔 地でバックアップを管理することも検討されている ${ }^{15)} 。$

本稿との課題からは逸れるが, 震災後の新たな動向之 して, 所有者からの放棄的な委託 (所有権の売却) の増 加がみられる。面積を緗め易くなったことは T 参事も認 めているが，過伐や伐採後の造・育林費用が捻出できな い事態の増加も想定され，懸念が残る。

\section{B 材取引の再構筑過程}

行政による支援体制としては各加工工場の被災に対 し，国は補正予算を組んで対応した。合板材取引に関し ても，2011 年度の第 $1 \cdot 3$ 次補正予算によって助成が行 われた。第 1 次補正予算では, 被災工場限定の流通コス 卜支援が行われた。具担当者による上, 第 1 次補正予算 では金額も量も多かったものの，当初製材原木のみが対 象で，「必要資材」と見做されなかったチップについて は含まれず，国へ改善を要求したといら。続く第 3 次補 正予算でも，同じく振替輸送費の助成が行われた。しか ここ第 3 次補正予算について, 県の担当者は「事業の 目的や助成金の使途に関する要件が厳しく,使いらららい

「締め切りが早いという2 点について改善すべきと主 張し, 前者は要望が聞き入れられ，ある程度改善された が，依然として中小企業にとっては戦しいものだったよ 
うだとしている。更に䝰でも合板工場復旧に向け, 整備 支援や輸送調整を行った畆 17 。

課題も多かったものの，これらの支援を受け釜石森組 でも県外への振り分け輸送を開始した。まず石川県 $\mathrm{H}$ 社, その後秋田県 A工場への輸送が試多られた。県森連仲介 によるH 社への輸送は2011 年夏に始まった。しかし取引 量は要望より 1 千 $\mathrm{m} 3$ 少なく, $\mathrm{H}$ 社からの打ち切りにより 実質 1 ケ月で終了した。その後，同じく県森連系統での A 工場への輸送が 2011 年 10 月に始まったが，県産材か らの放射性物質の検出や，秋田県内の地元業者からの反 発によって11月には終了した。

$H$ 社への輸送が中止になってから 2,3 月間は取引相 手が見つからなかったが，T 参事の知人であった商社員 の仲介により岐阜県 $\mathrm{M}$ 社との取引が開始されることと なった。ここでは個人的な慗がりが重要な働きをしてい たことが理解できる。2012 年 10 月時点でも B 材は県外 のみ一出荷されており，一番多いのはM社，次が宮城目 I 工場との取引である。どちらも商社を介しての取引で あり， $\mathrm{T}$ 参事は今後県森連を介さない取引にも力を入れ ることを検討している。今後も県内 $の$ 需要が回復するま では県外流通を維持し，回復以後も同社には卸し続ける 意向である。A・B 材を合わせた素材生産量が震災から2， 3 ケ月後には $65 \%$ ほどに落ち込んだものの, 2012 年には 9 割まで回復したといら事や，施業集約化によって生産 量を増やせる見込みもあるという事から，失われた素材 流通先をカバーできるような規模の新しい販路確保が必 要であることが分かる。一方合板単価の下落と合板工場 復旧の遅えが㲘念事項として残っている。

\section{4. 復興住宅に関する取り組み}

前項のような大口取引の他，様々なB 材利用促進事業 が行われている。とりわけ大きなものが復興住宅である。 この復興住宅は「森の販金箱」と名付けられ, 釜石森組・ 県森連・（株）リンデンバウム遠野（遠野市）・株式会 社結設計（東京都）の協力によって事業が動いている。 仮設住宅に地域材を使いたいといら考えが「森の貯金箱」 に結びついたという。建材の $99 \%$ に地元のスギ材が使う れており，また地元の職人を起用することでアフターケ アにも対応している。「森の貯金箱」の特徴は 1 坪 30 万という安価さである。この価格で家を建て，被災した 組合員一希望を率すことが狙いであったという。廉価さ を実現したのが，今回独自に編子出した「Forest Stock Building (FSB) 工法」である。これは，柱と同寸の角材 を並べホボトで締めつけて1枚のパネル壁にしたもの 安土台と桁に金物で固定する工法であり，通常の住宅の 2-3 倍の木を用いることができる。使用木材量と伐採量 を比べると，1棟建てるごとに1haの山を整備すること
ができる，とも言い換えられる。更にB材の使用によっ て洒格も抑えられる。またFSB 工法ならば人件費と工期 の短縮が可能である。更に解体・移設・増設が容易で, 高台八の移転も含め生活変化にも対応できるため, 土地 が䓂上げされても移築という形で壊さず再出発できる。 地場材へのこだわりやアフターケアまで考えた人材の起 用，被災者への思いからは， T参事の「地域に貢献寸る」 といら思いが同われる。

「森の貯金箱」は，遠野市・釜石市・大桘町の行政や 住宅施工業者, 森林組合が協働し復興住宅の提供を目指 す「上閉伊地域復興住宅協議会」で，プランの1つとし て紹介されることになったという。市担当者によると， 徐々に復與公営住宅の建設も視野に入れ始めるが，その 際復興計画の建築条件の中に地域材の割合などを定める ことで，協議会の意向を反映していくイメージであると いう。「地域材を使い，被災者に廉価な家を提供したい」 という思いが行政との連携で奏現性を帯びてきた。被災 者からの反心も良好である。しかし被災者の建築資金の 不足と，行政による土地利用計画が定まらないことに伴 う建設用地の不足が課題となっている。

\section{$\mathrm{V}$ まめと考察}

IV章から，釜石森組の復興を促進或いは妨げたと考え られる要因を 3 つ抽出した。それらを順に述べ，最後に 今後の対応策を考える。

\section{1.これまでの事業}

今回の事例では，震災以前から釜石森組が取り組んで いた事業が復興促進に役立った。被災直後でも，以前か らJ-VERに取り組んでいた為に企業と迅速に契約を結ぶ ことができ，その収入が資金不足を助けた。そもそも J-VER 発行はこれまでの施業による成果であることも述 べておきたい。更にA材生産への取組みは木材流通停滞 を最低限に抑えた一因となっている。県沿岸広域振興局 担当者から「釜石（森組）のようにA材も生産していた 所は比較的ダメージが小さいが，全てB材にしていた所 は蕨しいという見解が聞かれた。既述した県沿岸広域 振與局担当者は，「合板需要に頼りすぎた体系が問題。 合板へのシフトが急激過ぎたことも大きなダメージに繋 がったのではないかり と述べている。また石炭混焼発電 への取り組みも被害緩和に役立っている。今回の地震で は製紙工場も被災し，岩手県内の製紙用チップの流通が 停滞した為，材価は暴落している注 ${ }^{(8)}$ 。しかし釜石森組 ではC材を全て石炭混焼発電に回しており,この影響を 受けずに済んだのである。

\section{2.人的ネットワーク・各主体との連携の構筑}


地域コミュニティーが災害へのレジリアンスを獲得す るためには,民間団体同士,或いは民間と行政間でのネッ

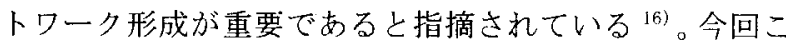
のようなネットワークが復興を促進する要因になってい ることが確認できた。

J-VER 販売では㝕口になった県森連との連携が見られ た。また被災後の資金不足を補うという面では市との連 携により瓦砅発注業務への参画が実現した。同じく被災 直後に組織を再編する際は OG や遠野地方森林組合の協 カがあった。これら㳇金石森組が震災直後の活動停滞を 避けるために貴重な応援であった。また復興住宅に関し ても地域内外での協㗢の取組みが見て取れる。「森の貯 金箱」が廉価での提供を実現できた背景には関係主体の 協力がある。「閉伊地域復興住宅協議会」も地元コミュ ニティーの協働による団体と言える。協議会の意向が市 の復興計画に反映される点からも民間と行政間の連携が 行われていると言える。バイオマス活用でも各主体の連 携が事業を回寸キーワードとなっている。例えば事業発 足時, 補助の受け入れに関しては行政との連携が機能し ていた。また週 1 回の事業主体による会合など，現在も 情報共有・協力体制が保持されている。そして施業集約 化への取り組みは釜石森組の人的ネットワークの賜物で ある。震災後はロコミによって消息を把握できたことは 既述のとおりである。また林業に関わる法律の改正に よって森林組合も大きな転換期を迎えているが，奨森連 H 氏は釜石森組について「今まで培った，組合員と身近 な会話ができる（信頼）関係は強み」と評している。

このように釜石森組の事例は，各主体間でのネット ワーク形成がレジリアンス獲得に重要であり，人的ネッ トワーク構筑のためには平時からの交流が必要という指 摘 ${ }^{17)}$ を体現していると言えよう。またこのネットワーク が復興の際だけでなく今後の発展を後押しする一因と なっていることが，上記バイオマス活用や施業集約化に ついて考察できる。

更にネットワーク形成の方法について，これまでの事 業が寄与していることも指摘したい。例としてB材取引 の展開と, 被災直後の J-VER 販壳を举げる。B 材の取引 では特に商社との繫がりが奇与した。Ｍ社とＩ工場との 取引は T 参事と商社員との親交がきっかけで始まった。T 参事によると，「大手企業とはJ-VER やバイオマス利用 での視察をきっかけに知り合い，商売を締結している」 という。ここから平時に行っている事業が人脈を形成す る要因として働いていると考察できる。被災直後の J-VER 販売を巡っては, 企業側で積極的に被災地の J-VER を購入する動きがあった ${ }^{(8)}$ 。釜石森組では震災以前に契 約を締結した K 社が率先して購入し，釜石森組の間伐材
を利用したノベルティーグッズの制作も行った。この一 連の動きの背景には，震災以前の J-VER 購入が生んだ連 携が指摘されている ${ }^{19)}$ 。J-VERによる収入は震災から復 旧する為の資金源として役立っていた。

\section{3. 行政の支援}

行政による費用の助成も復興を後押しした一因として 挙げられる。国からの振替輸送費助成については既に述 ベた通りである。助成によって遠方まで木材を輸送でき たため，この措置はある程度有用であったと言える。ま た震災の影響は殆ど受けていないが，木質バイオマス石 炭混焼発電にも助成が行われており，助成が発足と発展 を促進していると考えられる。一方で現場の実情を予算 に反映できていないなど課題も山積している。政策決定 プロセスの遅さや予算の使途の硬直化等については既に 苦言が呈されており ${ }^{\text {it } 19)}$ 対応の改善が待たれる。

\section{4. 今後の対応策として}

以上を踏まえ，地域の森林管理を担う主体やそれを支 える行政が取るべき対応について考察する。

今回の事例では平時の運営体制がリスク低減に役立つ たことからまずそれについて言及したい。初めに人的 ネットワークの構築について述べる。釜石森組には他主 体との平時からの交流を可能にした要因として，他主体 の関心を惹きつけるだけの「強み」があったことが考え られる。T 参事によると, 釜石森組の活動を知った企業 側からの働きかけから両者の連携が展開している。また 釜石森組では，国の方針に先駆けて取り組んだ木質バイ オマス活用事業などが人的ネットワーク構築に繋がって いる様子が伺え，新たな取引形態や事業の展開を試みる ことも有用と考えられる。このようにして運営体制を健 全化し，活力ある様子を発信していたことが他主体の関 心・信頼性を呼んだと考察される。次に，東北地方での B 材依存体制について, 木材の用途や出荷先を複数備え リスクに対する体制を整えるべきとの指摘がある ${ }^{20)}$ が， 今回そのリスクが顕在化した。事業の多角化という点か ら，これまでの事業を見直し改善していくことが当然求 められる心゙きである。また多様な販路を確保することも， 災害時の販路断絶の回避, 生産量増加時の対応の為に有 用と言えよう。今回の事例では，県森連系統だけでなく 商社を介した取引経路の確保が復興へ大きく寄与した。 加えて森林所有者との信頼関係を構築しておくことが団 体の発展のためには不可欠である。

次に平時の災害対策について触れたい。ここでは一極 集中の回避がポイントとなる。データやノウハウについ て，釜石森組での蓄積の喪失については既述の通りであ る。今回は「1 カ所の機器への蓄積」だけでなく「一部 の職員の経験」という点も問題であった。これに対し釜 
石森組は遠隔地へのデータのバックアップと職員内での 経験・情報の共有を試み始めている。同様の対策は他の 林業団体にも必要であろう。また上記の販路の多様化も 災害対策の一部と言える。

次に発㷋後について述べる。被害状況を確認し，その 長期化・深刻化を防ぐためには何が必要か，他主体にど んな協力を要請すべきかについての判断力が問われる。 ここでは平時に築いた人的ネットワークの活用が鍵とな る。また民間事業体や森林組合には，森林所有者等の一 般住民の生活再建に貢献するという責務もある。行政や 他主体の支援を有効に活用しつつ，早期の事業再開を目 指寸こと，被災後に生じた課題解決を通じて発災以前よ りも良い状態に「復興」することが望まれる。

\section{注}

注1）林野庁編『平成 24 年度版森林・林業白書』（一 般社団法人全国林業改良普及協会，2012）

注2）今井良広・金川幸司(2011)：震災復興過程におお打 るコミコニティ・ガバナンス：協働の枠組をめ ぐる国際比較(グローバリゼーションにおける社 会・経済システムの構想).社会・経済システム, $32,83-95$

注3）導入以前: $3.2 \mathrm{~m} 3 /$ 日/人，導入後: 約 $6 \mathrm{~m} 3 /$ 日/人（最 高 $9.2 \mathrm{~m} 3$ /日/人【2011】)

注4）釜石市 2009.12.28 臨時記者会見資料「緑のシステ 公創造事業について」

注5） $4 \cdot 5 \cdot 6$ 月汇融雪水による水力発電を行うため

注6） 7)8)9)日刊工業新聞 2011.4.21-2012.1.6 各号

注 10）岩手大学演習林土場でのアカマツチップ材売渡 価格:震災前 6500 円 $/ \mathrm{m} 3 \rightarrow 2011$ 年 10 月 1800 円 $/ \mathrm{m} 3$ 注11）12)13)14)15)日刊木材新聞 2011.11.9-2012.5.9各号 注16）注 10 を参照

注17）岩手県復興局（2011.8）「岩手県東日本大震災津 波復興計画 復興基本計画」
注18）注 10 を参照

注19) 山本（2011），香坂（2012）

\section{引用文献}

1）2）3）香坂玲（2012）：レジリアンスとは一生態学か ら社会経済分野八(香坂玲編，『地域のレジリアンス 大 災害の記憶に学ぶ』）清水弘文堂書房, 東京, pp.16-33 4) 高橋幸男(2009)：岩手県・釜石地方森林組合一集約化 施業の基盤としての境界確認活動（志賀和人編，『森林の 境界確認と団地化』) 林業改良普及双書, 東京, pp. 115-139 5）山本信次（2011）：東日本大震災後の青森県・岩手県 の林業・林産業の現状.林業経済，64(4), 19-28

6）7）JForest 全国森林組合連合会: 森林組合による組合 員所有林の集約化一釜石地方森林組合（岩手県釜石市）, $<$ http://www.zenmori.org/shiryou/h22 report/detail43.html $>$ 2013 年 4 月 8 日, 2013 年 4 月 15 日

8）多田忠義（2012）：東北地方に扮ける合板向け国産材 供給体制の実態.林業経済，58(1)，68-77

9）千田健哉（2011）：東日本大震災による岩手県森林組 合の被災と復興の状況メモ一被災後 2 少月頃の状況を中 心に一.林業経済，64(5)，12-15

10）武田八郎（2011）: 東日本大震災後の木材産業問題. 林業経済, 64(7), 5-7

11）坪谷克彦 (2007)：地域と一体になった森林整備の担 い手として地域と一体になった森林整備の担い手として 一釜石地方森林組合(岩手県).GR 現代林業, 496, 16-18

12）13）14）9に同じ

15） 5 に同じ

16）17） 1 に同じ

18）19）今野知樹 (2012)：震災復與と地域の森林管理 : オフセット・クレジット(J-VER)党活用した釜石地方森林 組合の取組について.菻林技術，840，13-17

20) 8 に同じ

Summary: This paper aims to review the reconstruction process of organizational systems, lumber production systems, forest management systems of the Kamaishi Forestry Cooperative that were affected by the East Japan Earthquake and Tsunami and study the elements that are required for local communities to attain disaster resilience based on them. This case study, as previous studies did, identified the partnership between human networks and local communities as a crucial factor. It further found that the high standard of the cooperative's pre-disaster operations in lumber production and forest management prompted their reconstruction キーワード (Keywords) : 社会関倸資本（social capital），東日本大震災（Great East Japan Earthquake）レシシリアンス (resilience），木材流通（wood circulation），木材利用（wood use） 